\title{
Lactic Acid Bacteria Fermentation of High Protein Feeds: The Effect of Molasses and Incubation Time on Improving Digestibility
}

\author{
P G Kinayang ${ }^{1}$, Z Bachruddin $^{1 *}$ and A Kurniawati ${ }^{1}$ \\ ${ }^{I}$ Laboratory of Nutritional Biochemistry, Faculty of Animal Science, Universitas of Gadjah Mada, Jalan Fauna \\ No: 3, Kampus UGM, BulaksumurYogyakarta, Indonesia, 55281 \\ *Corresponding author:bachrudin@ugm.ac.id
}

\begin{abstract}
This research aimed to find out the effects of molasses level addition as soluble carbohydrate sources and incubation time towards in vitro digestibility of fermented protein feed. The treatments given to the fermented protein concentrate were the level of molasses of 0,2 , and $4 \%$ and an incubation time of 0,7 , and 14 days. The treatments had three times replication. All the concentrate fermented by lactic acid bacteria, tempeh starter, and ethanol-fermentation starter. The fermentations were incubated at room temperature anaerobically. The best result of fermentation analyzed for Tilley and Terry in vitro digestibility. Therefore, the parameters observed were chemical composition, the digestibility value of the dry matter, organic matter, crude protein, and crude fiber. Chemical composition data analyzed by a completely randomized factorial design. In vitro digestibility data obtained analyzed by one-way design. The results obtained were significantly different due to the treatment then tested by Duncan Multiple Range Test (DMRT). The results showed that fermented protein concentrate which incubated within seven days with the use of 0,2 and $4 \%$ molasses has the best value on chemical composition, then the fermentation was checked for it is in vitro digestibility. The result suggested that use of molasses were significantly $(\mathrm{P}<0.05)$ affected the digestibility of dry and organic matter but were not significantly $(\mathrm{P}>0.05)$ affected the digestibility of crude protein and crude fiber.
\end{abstract}

\section{Keywords: Lactic Acid Bacteria, Protein, Digestibility.}

\section{INTRODUCTION}

The feed is livestock's primer source to maintain daily needs and productivity. Nevertheless, basal feed somehow cannot guarantee the fulfillment of microelements in the form of minerals, vitamins, and amino acids. Feed quality can be increased by combining some feed ingredients or adding feed supplements - it usually contains high carbohydrate and protein content - to reach optimal productivity.

Further treatment towards feed ingredients, such as the fermentation process, will also improve the quality of feed. Fermentation is an aerobic and anaerobic microbial activity which able to simplify the complex compounds then may convert low into high biological and economic values materials. The fermentation process of feed ingredients by microbes causes beneficial changes such as improving the quality of feed ingredients both from the nutritional and digestive aspects as well as increasing its shelf life due to a decrease in $\mathrm{pH}$ and production of organic compounds [1].

Fermentation can increase the digestibility of feed ingredients through the simplification of substances contained in feed ingredients by enzymes produced by microbes; therefore, the nutrient absorption in the digestive tract will be increased [2]. Fermentation can also enhance nutrients due to the production of fermented products or due to the development of microbes in the fermentation medium, causing the increase of microbial biomass [3]. Then, this process needs to be supported by adding nutrients to the fermentation media to support and stimulate microbial growth.

Fermentation is affected by microbial activity, $\mathrm{pH}$ value, temperature, water content, substrate content, and incubation time [4]. Fishery waste in the form of fish head and agricultural waste in the form of molasses can be used in the preparation of feed supplements. Molasses act as a soluble carbohydrate and provide carbon source in microbial cell formation. The length of incubation also determines the fermentation product, so it is necessary to know the right time to harvest fermented products. 
Thus, molasses addition as much as 0,2 and $4 \%$ and 0,7 and 14 days incubation were given as treatment in making high protein feeds in form of fermented concentrate. Based on these variation, it was suggested to get the best composition of fermented concentrate which can be useful as a new feed stuff which contain high level of protein as well as high digestibility to ruminant.

\section{MATERIAL AND METHOD}

This research is conducted at the Laboratory of Nutrition Biochemistry, Department of Animal Nutrition and Food, Faculty of Animal Husbandry, Universitas Gadjah Mada. The variable consisted of the proximate analysis of feed components and in vitro digestibility. The tools used were in vitro tubes, water bath, thermometer, thermos, $\mathrm{CO}_{2}$ gas, and analytical scales. The materials used were corn flour, soybean meal, fish meal, water, molasses, and starter of lactic acid bacteria, tempeh yeast, and ethanol-fermentation starter.

\subsection{Fermentation of Concentrate}

The fermented protein concentrate consists of three types of feed ingredients: fish waste flour, Distiller's Dried Grains with Soluble (DDGS), and soybean meal. There were three treatments with different concentrations of molasses added namely treatment I with no addition of molasses, treatment II with the addition of $2 \%$ of molasses, and treatment III with the addition of $4 \%$ of molasses. The concentrate mixture was steamed for 30 minutes at $99^{\circ} \mathrm{C}$, after being moderated, then inoculated with $50 \mathrm{~g}$ lactic acid bacteria (LAB), 50 $\mathrm{g}$ tempeh starter, and $50 \mathrm{~g}$ ethanol-fermentation starter. The microbial starter had colony number as many as $3.05 \times 10^{6} \mathrm{CFU} / \mathrm{ml}$ of LAB, $2.9 \times 10^{6}$ $\mathrm{CFU} / \mathrm{ml}$ of tempeh starter, and $2 \times 10^{6} \mathrm{CFU} / \mathrm{ml}$ of ethanol-fermentation starter. The feed mixture was stored in airtight plastic and incubated at room temperature for 0,7 and 14 days - the composition of fermented protein concentrate displayed in Table 1.

Table 1. Fermented feed concentrate formulation

\begin{tabular}{cccc}
\hline \multirow{2}{*}{ Feedstuff } & \multicolumn{3}{c}{ Treatment } \\
\cline { 2 - 4 } & I & II & III \\
\hline Fish waste flour (kg) & 0.5 & 0.5 & 0.5 \\
Soy bean meal (kg) & 0.5 & 0.5 & 0.5 \\
DDGS (kg) & 2 & 2 & 2 \\
Water (ml) & 1450 & 1430 & 1400 \\
Molasses (ml) & 0 & 90 & 180 \\
\hline
\end{tabular}

The fermented protein concentrates were kept in plastic bags that were heat resistant, thick, and transparent. Each treatment replicated six times. The fermented protein concentrates were incubated for 0,7 and 14 days at room temperature. The nutrient contents checked with samples which had been dried in a dry oven at $55^{\circ} \mathrm{C}$ then analyzed with the proximate method [5] including dry matter, organic matter, crude protein, crude fiber, and ether extract. The results of the proximate analysis used as the basis for selecting the best-fermented protein concentrate which then tested for in vitro digestibility which includes digestibility of dry matter, organic matter, crude protein, and crude fiber.

\subsection{In Vitro Digestibility Test}

In vitro digestibility examined by Tilley and Terry method using sample preparation, medium preparation, and preparation of rumen fluid. In vitro digestibility tests consisted of two stages that reflected digestibility in the rumen and post-rumen. The stages carried out in a tube that has been filled with one part of the rumen fluid and four parts of artificial saliva or a buffer solution that combined and functioned as an artificial rumen. The digestion process in the artificial rumen lasted for 48 hours, then collected; meanwhile, the second stage was the digestive process after the rumen lasted for 96 hours, then collected. In vitro residues were then tested for proximate analysis of its dry matter, organic matter, crude protein, and crude fiber.

\subsection{Data Analysis}

Data obtained were chemical composition and in vitro digestibility. Chemical composition data analyzed by variance analysis with a completely randomized design of factorial pattern. Dry matter, organic matter, crude protein, and crude fiber data from the best-fermented protein concentrate digestibility were analyzed by one way ANOVA, if the results of the variance analysis had a significant effect on one variable, then the analysis continued with Duncan's New Multiple Range Test (DMRT) test. 


\section{RESULT AND DISCUSSION}

\subsection{Chemical Composition of Fermented Protein Concentrates}

The results of fermented protein concentrates were tested for nutrient composition, including dry matter, organic matter, crude protein, crude fat, and crude fiber. Fermentation can reduce dry feed matter as the result of microbial activity. Microbes can break down complex nutrient to the simpler one made it easy to be digested by livestock. However, many nutrients wasted in the form of $\mathrm{CO}_{2}$ and $\mathrm{NH}_{3}$ and water. The decreased dry matter will perform impact on decreasing organic matter. The decreased dry matter content in feed ingredients was due to nutrients break down by fungi, which produced metabolites during substrate hydrolysis [6].

Based on the data in Table 2, it is known that the content of dry matter and organic matter between fermented proteins concentrates with an incubation time of 7 days and 14 days did not differ significantly $(\mathrm{P}>0.05)$. It means that the duration of fermentation can maintain the levels of dry matter and fermented protein concentrate organic matter. Decreasing the dry matter of fermented material is influenced by respiration and fermentation. Respiration will cause a lot of nutrient content to decompose by fungi so that reduce dry matter, while fermentation will produce lactic acid and water [7]. Therefore, respiration occurred in the early days of fermentation so that nutrient is broken down and impacted on reducing dry matter and organic matter which is inevitable, but then the fermentation process occurred and can maintain the composition of dry matter and organic matter until the 14th day.

The chemical composition of fermented protein concentrates with the addition of molasses as soluble carbohydrates sources and incubation time can be seen in Table 2 .

Table 2. Effect of the addition of molasses as a source of soluble carbohydrates sources at different levels and incubation time to the chemical composition of fermented protein concentrates

\begin{tabular}{|c|c|c|c|c|c|}
\hline \multirow{2}{*}{$\begin{array}{c}\text { Nutrient } \\
\text { components }\end{array}$} & \multirow{2}{*}{$\begin{array}{l}\text { Incubation } \\
\text { time (days) } \\
\end{array}$} & \multicolumn{4}{|c|}{ Level of molasses (\%) } \\
\hline & & 0 & 2 & 4 & Average \\
\hline \multirow{4}{*}{ Dry matter (\%) } & 0 & $56.768 \pm 1.838$ & $58.220 \pm 1.720$ & $58.499 \pm 0.714$ & $57.829^{\mathrm{b}}$ \\
\hline & 7 & $48.094 \pm 1.542$ & $50.833 \pm 0.410$ & $52.998 \pm 1.866$ & $50.642^{\mathrm{a}}$ \\
\hline & 14 & $50.380 \pm 3.720$ & $50.488 \pm 0.185$ & $51.025 \pm 2.179$ & $50.631^{\mathrm{a}}$ \\
\hline & Average & $51.747^{\mathrm{a}}$ & $53.180^{\mathrm{ab}}$ & $54.174^{\mathrm{b}}$ & \\
\hline \multirow{4}{*}{$\begin{array}{l}\text { Organic matter } \\
\text { (\%DM) }\end{array}$} & 0 & $79.897 \pm 1.275$ & $80.257 \pm 0.238$ & $80.025 \pm 1.838$ & $80.059^{\mathrm{b}}$ \\
\hline & 7 & $76.268 \pm 1.610$ & $77.384 \pm 0.860$ & $77.941 \pm 2.098$ & $77.198^{\mathrm{a}}$ \\
\hline & 14 & $77.800 \pm 2.023$ & $77.364 \pm 1.573$ & $76.596 \pm 2.455$ & $77.254^{\mathrm{a}}$ \\
\hline & Average $^{\mathrm{ns}}$ & 77.988 & 78.187 & 78.335 & \\
\hline \multirow{4}{*}{$\begin{array}{l}\text { Crude protein } \\
\text { (\%DM) }\end{array}$} & 0 & $49.084 \pm 1.582$ & $45.331 \pm 1.097$ & $45.698 \pm 0.629$ & $46.704^{\mathrm{a}}$ \\
\hline & 7 & $76.429 \pm 1.818$ & $61.373 \pm 1.637$ & $47.834 \pm 1.919$ & $61.879^{\mathrm{c}}$ \\
\hline & 14 & $64.110 \pm 5.479$ & $51.060 \pm 1.437$ & $43.985 \pm 2.308$ & $53.052^{\mathrm{b}}$ \\
\hline & Average & $63.208^{\mathrm{a}}$ & $52.588^{\mathrm{b}}$ & $45.839^{\mathrm{c}}$ & \\
\hline \multirow{4}{*}{$\begin{array}{l}\text { Extract ether } \\
(\% \mathrm{DM})\end{array}$} & 0 & $4.401 \pm 0.440$ & $4.735 \pm 0.110$ & $4.622 \pm 0.232$ & $4.586^{\mathrm{a}}$ \\
\hline & 7 & $7.227 \pm 0.397$ & $4.910 \pm 0.420$ & $5.680 \pm 0.474$ & $5.939^{c}$ \\
\hline & 14 & $4.847 \pm 0.421$ & $5.777 \pm 0.422$ & $4.974 \pm 0.484$ & $5.199^{b}$ \\
\hline & Average $^{\mathrm{ns}}$ & 5.492 & 5.141 & 5.092 & \\
\hline \multirow{4}{*}{$\begin{array}{l}\text { Crude fiber } \\
\text { (\%DM) }\end{array}$} & 0 & $10.678 \pm 0.834$ & $9.911 \pm 0.726$ & $9.245 \pm 0.413$ & $9.9449^{\mathrm{a}}$ \\
\hline & 7 & $12.669 \pm 0.279$ & $11.330 \pm 0.286$ & $10.338 \pm 0.739$ & $11.446^{\mathrm{b}}$ \\
\hline & 14 & $13.503 \pm 1.083$ & $11.565 \pm 0.325$ & $10.306 \pm 0.571$ & $11.792^{\mathrm{b}}$ \\
\hline & Average & $12.283^{\mathrm{c}}$ & $10.935^{\mathrm{b}}$ & $9.963^{\mathrm{a}}$ & \\
\hline
\end{tabular}

a, b, c Different superscripts on the same row or column show significantly different $(\mathrm{P}<0.05)$

${ }^{n s}$ Non significant

Organic matter includes crude protein, crude fiber, and crude fat. Proteins in feed ingredients are generally proteins from plant and with fermentation, it will be converted into microbial proteins. Crude protein was increased from the incubation time of 0 to 7 days. Crude protein of fermented protein concentrate increased due to the activity of microbes and the addition of proteins found in microbial cells themselves. An increase in crude protein content in fermentation occurs 
because of the results of hydrolysis of starch to sugar as long as the fungi degrade and dissolve the substrate used by fungi as a source of carbohydrates to synthesize fungi biomass which is rich in protein [8].

Based on the results, the crude protein content in the fermented protein concentrate increased on seven days incubation then decreased on the 14 days incubation. It happens due to more prolonged incubation, which can cause more feed nutrients to be degraded and used to suffice microbial needs. Crude protein content during incubation will undergo a decline due to microbial activity [8]. Proteolysis clostridia will ferment amino acids into various products, including ammonia, amines, and volatile organic acids [9].

Another organic component is crude fiber. Based on the data in Table 2, the longer the incubation will increase the crude fiber, but the higher the addition of molasses will lower the crude fiber. Another study explained for 0 to 50 hours of tempeh fermentation, the growth of Rhizopus sp. continued to increase by producing mycelia on the

Table 3. Effect of different addition of molasses as a source of soluble carbohydrate source towards digestibility of 7 days incubation fermented protein concentrate.

\begin{tabular}{|c|c|c|c|}
\hline \multirow{2}{*}{$\begin{array}{c}\text { Nutrient } \\
\text { components }\end{array}$} & \multicolumn{3}{|c|}{ Level of molasses $(\%)$} \\
\hline & 0 & 2 & 4 \\
\hline $\begin{array}{ll}\text { Dry matter } \\
(\%)\end{array}$ & $\begin{array}{l}83.0832 \pm \\
1.50449^{\mathrm{a}}\end{array}$ & $\begin{array}{l}81.9376 \pm \\
4.39586^{\mathrm{a}}\end{array}$ & $\begin{array}{l}89.13699^{ \pm} \\
0.53843^{\mathrm{b}}\end{array}$ \\
\hline $\begin{array}{l}\text { Organic } \\
\text { matter } \\
(\% \mathrm{DM})\end{array}$ & $\begin{array}{l}80.8070 \pm \\
1.50937^{\mathrm{a}}\end{array}$ & $\begin{array}{l}80.7192 \pm \\
5.67106^{\mathrm{a}}\end{array}$ & $\begin{array}{l}88.1863 \pm \\
0.14141^{\mathrm{b}}\end{array}$ \\
\hline $\begin{array}{l}\text { Crude } \\
\text { protein } \\
(\% \mathrm{DM})^{\mathrm{ns}}\end{array}$ & $\begin{array}{l}58.0169 \pm \\
6.61276\end{array}$ & $\begin{array}{l}44.7651 \pm \\
6.29237\end{array}$ & $\begin{array}{l}50.6221 \pm \\
5.14009\end{array}$ \\
\hline $\begin{array}{l}\text { Crude fiber } \\
(\% \mathrm{DM})^{\mathrm{ns}}\end{array}$ & $\begin{array}{l}32.8155 \pm \\
2.96221\end{array}$ & $\begin{array}{l}38.6001 \pm \\
2.96221\end{array}$ & $\begin{array}{l}36.3287 \pm \\
5.74598\end{array}$ \\
\hline $\begin{array}{l}\text { a, b Different } \\
\text { significantly } \\
\text { ns Non signific }\end{array}$ & uperscripts & $\begin{array}{l}\text { on the sam } \\
05 \text { ) }\end{array}$ & row show \\
\hline
\end{tabular}

Dry matter digestibility is one indicator to determine feed quality. The higher the digestibility of dry matter, the higher the chance of nutrients that can be utilized by livestock for the growth of ruminants and microbes in the rumen. The addition of molasses to dry matter digestibility of 7 days incubation fermented concentrate was significantly different $(\mathrm{P}<0.05)$. The average dry matter digestibility between the addition of 0 and $2 \%$ molasses was not significantly different, but the surface of the soybean seeds which were increasingly thick and formed a more compact mass of tempeh. Increased number of mycelia formed by Rhizopus sp. during the process of tempeh fermentation indicates an increase in the content of tempeh crude fiber [10].

\subsection{In Vitro Digestibility of Fermented Protein Concentrates}

Based on the proximate analysis, it was found that the concentrates incubated within 7 days were better than the concentrates incubated for 0 and 14 days. The dry matter content of 7 and 14 days fermented concentrate had relatively the same level which was also higher than 0 day incubation. However, according to its crude protein, 7 days fermented concentrate had higher level than the 14 days. Thus, based on these data, fermented protein concentrates which incubated for seven days were tested to find out the effect of molasses addition as soluble carbohydrates source towards its digestibility

addition of $4 \%$ molasses was significantly different. The highest dry matter digestibility was also found in the concentrate with the addition of $4 \%$ molasses.

Microbes added in fermentation processes such as $R$. oligosporus, $S$. cerevisiae, and lactic acid bacteria played a significant role in producing extracellular enzymes. These enzymes help in degrading organic materials such as carbohydrates, fats, and proteins to increase organic matter digestibility, which then also increases dry matter digestibility. The presence of soluble carbohydrate sources in the form of molasses allows the higher and rapid growth of microbes, so the production of extracellular enzymes that degrade dry matter also increases. Besides, $S$. cerevisiae is known for its ability to bind or utilize oxygen so that it will create an anaerobic atmosphere faster in the rumen [11]. In a faster anaerobic atmosphere, microbial growth increases, especially cellulolytic bacteria, then it may affect the degradation of crude fiber and in turn, increases the digestibility of ration dry matter [12].

Along with dry matter digestibility, fermented concentrates have higher digestibility compared to non-fermented concentrates. Fermented concentrates contain organic matter, which is easily digested compared to non-fermented concentrates [12]. There was no significant difference $(\mathrm{P}>0.05)$ of crude protein digestibility at all levels of molasses. The highest digestibility rate is found in fermented protein concentrates without the addition of molasses. It may occur due to the presence of 
fungi which are thought to be $R$. oligosporus which presented in concentrated samples with $0 \%$ molasses. Rhizopus oligosporus produces protease enzymes with high proteolysis activity as in the fermentation of tempeh production and does not produce toxin [13].

Rhizopus sp is a fungus that can produce protease enzymes. The protease enzyme can catalyze the hydrolysis of peptide bonds into short oligopeptides and free amino acids. These free peptides and amino acids are more easily absorbed by the body compared to long-chain proteins. Some peptides are also bioactive, which can improve animal health because it functions as antimicrobial, anti-inflammatory, and immunomodulatory agents [14].

The advantages of fermented protein concentrate are from the addition of the $R$. oligosporus. Fungi use nutrients from the concentrate to support their growth. Furthermore, the fungus multiplies to form spores, which will cover a portion of the concentrated particles. It allows the bond between chitin to form the fungal cell wall with the protein in the concentrate, thus causing the protein to be challenging to break down by the rumen microbes.

Chitin substances in nature are generally not free but are bound to proteins and minerals. It causes the content of organic matter, especially protein in fermented concentrates to be resistant to microbial degradation in the rumen, but can be digested enzymatically in the post rumen, because chitin can only dissolve in concentrated mineral acids such as $\mathrm{HCl}$ [15].

Crude fiber digestibility in all three level molasses addition treatments was not significantly different $(\mathrm{P}>0.05)$. The highest crude fiber digestibility rate of fermented protein is in the concentrate with $2 \%$ molasses. The digestibility of crude fiber with 2 and $4 \%$ of molasses increased compared to concentrates without the addition of molasses. It is due to the increase in the number of microbes that can produce cellulase enzymes to degrade crude fiber.

\section{CONCLUSION}

Fermented protein concentrates shown to have higher digestibility than non-fermented concentrates. The importance of using concentrates in rations is to meet nutrient intake for livestock. Fermented protein concentrate provide easily digested nutrients than non-fermented concentrates because it has been simplified by the activity of microbes.

\section{ACKNOWLEDGMENT}

The authors would like to thank to Universitas Gadjah Mada for the grant under the scheme of Rekognisi Tugas Akhir (RTA) with contract No.2129/UNI/DITLIT/DIT-LIT/LT/2019.

\section{REFERENCES}

[1] Sugiharto S, Ranjitkar S. Recent advances in fermented feeds towards improved broiler chicken performance, gastrointestinal tract microecology and immune responses: A review. Anim Nutr [Internet]. 2019;5(1):1-10. Available from: https://doi.org/10.1016/j.aninu.2018.11.001

[2] Raza A, Bashir S, Tabassum R. An update on carbohydrases: growth performance and intestinal health of poultry. Heliyon [Internet]. 2019;5(4):e01437. Available from: https://doi.org/10.1016/j.heliyon.2019.e01437

[3] Nkhata SG, Ayua E, Kamau EH, Shingiro JB. Fermentation and germination improve nutritional value of cereals and legumes through activation of endogenous enzymes. Food Sci Nutr. 2018;6(8):2446-58.

[4] Samadi S, Wajizah S, Usman Y, Riayatsyah $\mathrm{D}$, Firdausyi $\mathrm{Z}$ Al. Improving Sugarcane Bagasse as Animal Feed by Ammoniation and Followed by Fermentation with Trichoderma harzianum (In Vitro Study). Anim Prod. 2016;18(1):14.

[5] AOAC. Official Methods of Analysis. Washington: Association of Official Analytical Chemists; 2005.

[6] Suparjo, Wiryawan KG, Laconi EB, Mangunwidjaja D. Perubahan Komposisi Kimia Kulit Buah Kakao akibat Penambahan Mangan dan Kalsium dalam Biokonversi dengan Kapang Phanerochaete chrysosporium. Media Peternak. 2009;32(3):203-10.

[7] Surono, Soejono M, Budhi SP. Kehilangan Bahan Kering dan Bahan Organik Silase Rumput Gajah pada Umur Potong dan Level Aditif yang Berbeda. Jurnal Indones Trop Anim Agric [Internet]. 2006;31(1):62-8. Available from: http://www.jppt.undip.ac.id/pdf/31(1)2006p62 $-67 . p d f$

[8] Mulia DS, Mudah M, Maryanto H, Purbomartono C. Fermentasi Ampas Tahu Dengan Aspergillus niger Untuk Meningkatkan Kualitas Bahan Baku Pakan Ikan. Semin Nas Hasil-hasil Penelit dan Pengabdi LPPM UMP. 2014;336-45.

[9] Wallace RJ, Chesson A. Biotechnology in 
Animal Feeds and Animal Feeding [Internet]. New York: VCH Publishers Inc; 1995. Available from: http://newcatalog.library.cornell.edu/catalog/2 731522

[10] Kasmidjo RB. Tempe: Mikrobiologi dan Biokimia Pengolahan Serta Pemanfaatannya. Yogyakarta: UGM Press; 1990.

[11] Wina E. Pemanfaatan Ragi (yeast) sebagai Pakan Imbuhan untuk Meningkatkan Produktivitas Ternak Ruminansia. Wartazoa. 1999;9(2):1-8.

[12] Lydia IH, Hernaman I, Tanuwiria UH. Pengaruh Penggunaan Konsentrat Fermentasi dalam Ransum Sapi Perah Berbasis Campuran Jerami Padi dan Daun Kaliandra (Calliandra calothyrsus) terhadap Kecernaan Bahan Kering dan Bahan Organik (In Vitro). J UNPAD. 2015;4(2).

[13] Ikasari L, Mitchell DA. Protease production by Rhizopus oligosporus in solid-state fermentation. World J Microbiol Biotechnol. 1994;10(3):320-4.

[14] Endrawati D, Kusumaningtyas E. Beberapa Fungsi Rhizopus sp dalam Meningkatkan Nilai Nutrisi Bahan Pakan. Wartazoa. 2017;27(2):81-8.

[15] Savitri E, Soeseno N, Adiarto T. Sintesis Kitosan, Poli (2-amino-2deoksi-D-Glukosa), Skala Pilot Project dari Limbah Kulit Udang sebagai Bahan Baku Alternatif Pembuatan Biopolimer. Pros Semin Nas Tek Kim. 2010;1-9. 